\title{
RHEUMATOID ARTHRITIS IN MALES
}

\section{AN EPIDEMIOLOGICAL STUDY OF A WELSH MINING COMMUNITY}

\author{
BY \\ W. E. MIALL \\ Medical Research Council, Pneumoconiosis Research Unit, Llandough Hospital, Cardiff
}

(RECEIVED FOR PUBLICATION JANUARY 17, 1955)

Caplan (1953) suggested for the first time in Great Britain that some cases of rheumatoid arthritis amongst coalminers with pneumoconiosis can be recognized from a characteristic chest $x$-ray appearance. An epidemiological investigation of this new syndrome showed that this nodular lung fibrosis (Fig. 1, opposite), was associated with rheumatoid arthritis in more than 50 per cent. of cases; it also suggested that the prevalence of rheumatoid arthritis was increased amongst men with complicated pneumoconiosis (Miall and others, 1953).

To determine whether the progressive massive fibrosis (P.M.F.) of complicated pneumoconiosis was an aetiological factor in the development of the arthritis, a survey of rheumatoid arthritis was undertaken in a Welsh mining valley where P.M.F. was known to be common amongst the miners. This paper describes further investigations into the relationship between rheumatoid arthritis and pulmonary disease.

A previous $x$-ray survey of the Rhondda Fach had shown that the prevalence of massive fibrosis rose from over 10 per cent. in the 35-39 age group to over 20 per cent. in the $65+$ age group (Cochrane and others, 1952), and the present survey was therefore carried out during the "follow-up" chest $x$-ray survey of the Rhondda Fach, undertaken by the M.R.C. Pneumoconiosis Research Unit and the Welsh Regional Hospital Board during the summer of 1953.

\section{Methods}

(1) Preliminary Screening.-The valley population was defined by private census immediately before the $x$-raying started in each town, and during this census a note was made of all individuals said to be suffering from any form of arthritis. 90 per cent. of the complete population over the age of 15 was subsequently $x$-rayed (Cochrane and others, 1955), and each individual as he attended for $x$ ray was asked whether he had suffered or was suffering from painful swellings of the small joints of the hands or feet.
Lists of cases of rheumatoid arthritis were provided from the medical practitioners in the valley and from theo rheumatism clinic serving the district. From these fouro sources, supplemented later by information obtained from patients who were found to have rheumatoidi arthritis, a list was compiled of individuals with rheumaticcomplaints; they were visited subsequently by the author,, who completed the preliminary screening with a historyo and brief clinical examination.

(2) Diagnostic Criteria.-In epidemiological surveys it is essential that the findings of different observers should be्ठ comparable. Any differences in the results of surveys undertaken by different workers can often be more confidently attributed to the diagnostic standards usad than to true differences in the prevalence of diseage especially is this true when assessment is made subjective evidence alone. Real epidemiological differ ences are only likely to be found when some objective evidence is incorporated in the diagnostic criteria usedo so that direct comparisons can be made.

In this survey, the diagnosis was based upon a charac $\vec{\not}$ teristic history of a polyarthritis involving periphera 5 joints, whether residual physical signs were present or absent, supported by either radiological evidence of rheumatoid arthritis in the hands or feet, or by a positive differential agglutination test (Rose and others, 1948 Ball, 1952). In field survey work a reproducible diagnosis at a rather high level of severity is more valuable than $\underset{\mathbb{Z}}{\mathbb{Z}}$. non-reproducible one at a lower level. Observer erron in the interpretation of radiographs of bony structures has been investigated by Kellgren and Lawrence (1952 and shown to be slight. Our previous investigations cons firmed that the observer error between two rheuma $>$ tologists reading films for evidence of rheumatois. arthritis is small (Miall and others, 1953) and a more recent investigation showed that, though the observep error between experienced and inexperienced readers is greater, agreement in the interpretation of $x$ rays of the hands and feet was found in 191 of 223 pairs of films. In 91 of these pairs evidence of rheumatoid arthritis was agreed to be present; in one hundred pairs it was agrees to be absent. In 32 films there was disagreemento largely due to the interpretation by inexperienced readers of the changes of generalized osteo-arthritis as rheumatoido arthritis with secondary osteo-arthritis. 


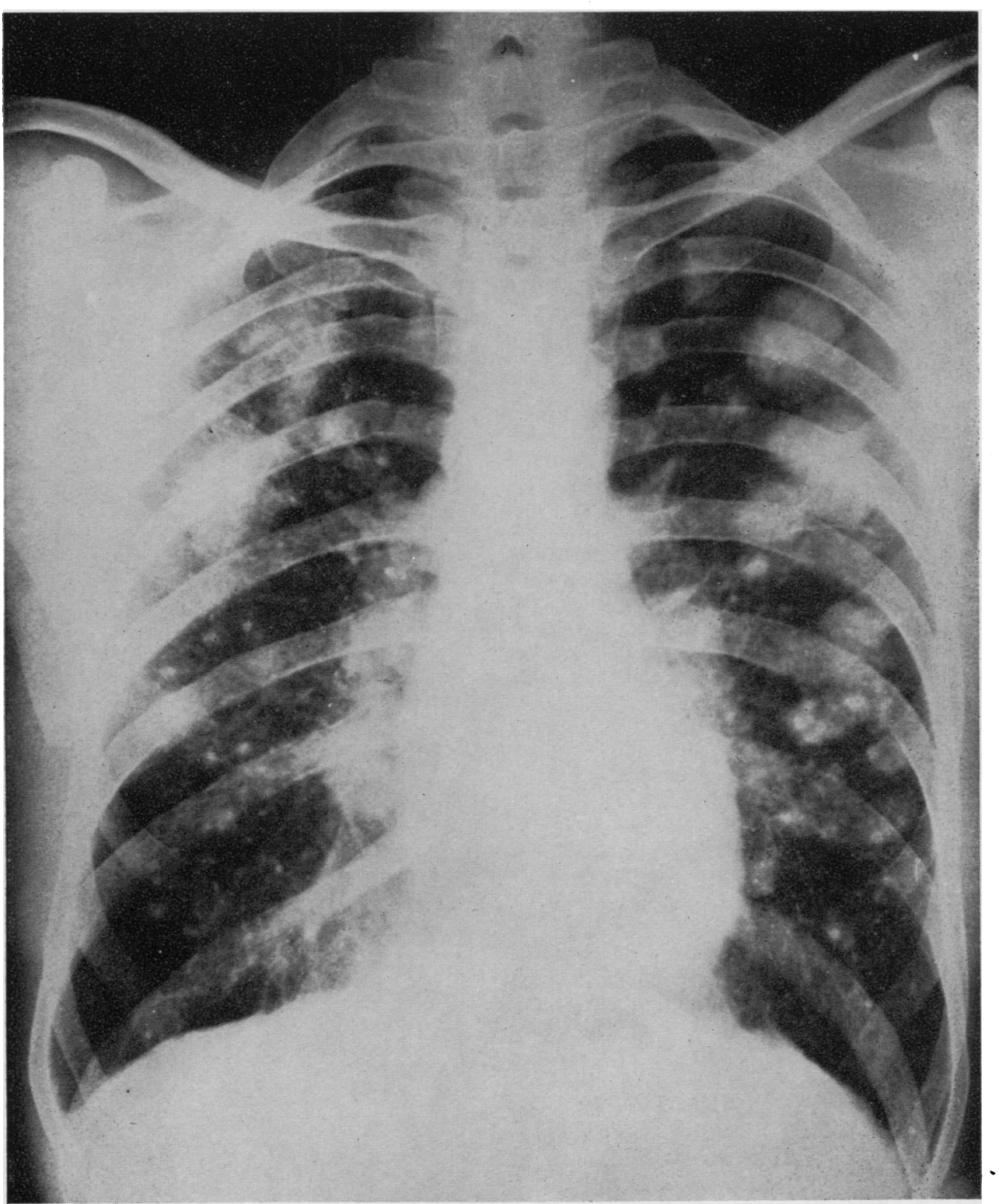

Fig. 1.-Typical example of nodular lung fibrosis associated with rheumatoid arthritis in coal workers.

No evidence is available about variation between laboratories on the results of the differential agglutination test carried out on the same sera, but this is likely to be small provided the same techniques are adopted and the criteria of positivity stated.

It is certain that, by using these rather strict criteria, some cases of rheumatoid arthritis have been missed: monarticular cases, for example, are excluded and also those in which only the larger central joints are involved. In the Empire Rheumatism Council's inquiry into the aetiological factors associated with rheumatoid arthritis (Lewis-Faning, 1950), 532 cases of rheumatoid arthritis of less than 5 years' duration were studied. Although a selected group of hospital in-patients, and therefore not comparable for frequency of symptoms or signs with a complete population of cases of this disease, an analysis 
showed that peripheral joints were involved in 98 per cent., so the initial selection of cases on the basis of a history of a peripheral polyarthritis should have excluded few cases of a severity warranting admission to a centre specializing in the treatment of rheumatism. On the other hand, by using these criteria, a number of cases of generalized osteo-arthritis (Kellgren and Moore, 1952) have been rejected, which, from their histories and residual signs, would not have been distinguished from inactive rheumatoid arthritis.

So, with the exception of the bedridden, all who were judged to be possible cases of rheumatoid arthritis were asked to submit to radiological examination of the hands and feet as well as of the chest, and to have a blood test.

\section{(3) Groups Studied}

(a) Cases of Arthritis.-Some information about the total population of 9,430 males over the age of 15 was obtained from the census takers, the general practitioners, and the local rheumatism clinic, but only 8,653 men (92 per cent.) were directly questioned about arthritis.

274 men were interviewed and medically examined, and 78 of these were considered to be cases of rheumatoid arthritis, but only 66 of them satisfied the strict criteria adopted, and these form the group studied in this paper. Of the twelve remaining men, who were considered to be definite or probable cases of rheumatoid arthritis, four had some residual signs, but proof of rheumatoid arthritis was impossible using these criteria. $X$ rays were taken of the peripheral joints of seventeen other men, who gave doubtful histories and had either no residual signs or residual signs of generalized osteo-arthritis, and nine of them also had the differential agglutination test performed, but all failed to fulfil the criteria adopted.

The results of the survey amongst females, in whom cases of polyarthritis which do not satisfy these criteria are more common, and a comparison of the prevalence in the two sexes, will be reported later.

(b) Controls.-For studies of chest $x$-ray abnormalities, industrial histories, and family histories amongst cases of rheumatoid arthritis, it was important to have control groups similar to the rheumatoid group in all respects, except that of rheumatoid arthritis. All data for the complete population of the valley had been transferred to punched cards and these were used for random selection of age-balanced control groups from the appropriate populations of miners and non-miners.

\section{Results}

(a) Radiography of Hands and Feet.-Radio graphs were taken of the hands and feet of sixty of the 66 cases and of the hands only in one other case? Of the five remaining, three were bedridden, and two refused to have $x$ rays taken.

These $x$ rays were kindly read by Prof. J. H들 Kellgren, who was asked to classify them into fou호․ grades: severe, moderate, and slight changes of rheumatoid arthritis, and normal. A set of controp bones was used to facilitate the diagnosis of osteow porosis.

20 per cent. of the whole group showed no radio logical changes in peripheral joints, and werew accepted as cases of rheumatoid arthritis on the basis of their clinical findings, supported by positive differential agglutination test.

(b) Differential Agglutination Test.-A modifica tion of the Rose agglutination test (Ball, 1950) waso used by Dr. J. Ball who has reported the results ine greater detail (Ball, 1955). The test was carried out on 64 of the 66 cases and was negative (i.e. noo agglutination at a dilution of $1: 4 \mathrm{at} 1 \mathrm{hr}$, or of $1: 32$ at $18 \mathrm{hrs}$ ) in ten cases ( 15 per cent.), who were therefore accepted as cases of rheumatoid arthritise on the basis of their clinical findings supported \&y. $x$-ray changes in the peripheral joints.

(c) Prevalence.-The prevalence of rheumatoid arthritis amongst all males, miners, and non-minerso is shown in Table I. Fig. 2 (opposite) compares that市 amongst miners and non-miners. Because of the small numbers involved, cases have been grouped into 10-year age groups, selected as shown, to give a smooth curve. When analysed in 5-year age्ठ groups a significant difference occurs in only the 40-44-year age group $(P=0 \cdot 04)$. Little impor $-\frac{\overline{0}}{2}$ tance should be attached to a significant differenceo at this level in only one of the nine 5-year age groups The overall difference in prevalence between minerso and non-miners is not significant; the prevalence of arthritis amongst the non-miners is, however, based음

TABLE I

PREVALENCE OF RHEUMATOID ARTHRITIS AMONGST ALL MALES, MINERS AND EX-MINERS, AND NON-MINERS (RHONDDA FACH, 1953)

\begin{tabular}{|c|c|c|c|c|c|c|c|c|c|}
\hline \multirow{2}{*}{$\begin{array}{l}\text { Age } \\
\text { Group } \\
\text { (yrs) }\end{array}$} & \multicolumn{3}{|c|}{ All Males } & \multicolumn{3}{|c|}{ Miners and Ex-Miners } & \multicolumn{3}{|c|}{ Non-Miners } \\
\hline & Total & No. & Per cent. & Total & No. & Per cent. & Total & No. & Per cent. \\
\hline $\begin{array}{c}15-19 \\
20-29 \\
30-39 \\
40-49 \\
50-59 \\
60+\end{array}$ & $\begin{array}{r}892 \\
1,688 \\
1,846 \\
1,737 \\
1,470 \\
1,797\end{array}$ & $\begin{array}{r}-3 \\
5 \\
17 \\
21 \\
20\end{array}$ & $\begin{array}{l}-\overline{0} \cdot 18 \\
0 \cdot 27 \\
0 \cdot 98 \\
1 \cdot 43 \\
1 \cdot 11\end{array}$ & $\begin{array}{r}310 \\
754 \\
1,204 \\
1,333 \\
1,281 \\
1,631\end{array}$ & $\begin{array}{r}-1 \\
3 \\
15 \\
18 \\
17\end{array}$ & $\begin{array}{l}-\overline{0} \cdot 13 \\
0 \cdot 25 \\
1 \cdot 13 \\
1 \cdot 41 \\
1 \cdot 04\end{array}$ & $\begin{array}{l}582 \\
934 \\
642 \\
404 \\
189 \\
166\end{array}$ & $\begin{array}{l}\overline{2} \\
\mathbf{2} \\
\mathbf{2} \\
3 \\
3\end{array}$ & $\begin{array}{l}-\overline{0} .21 \\
0.31 \\
0 \cdot 50 \\
1 \cdot 59 \\
1 \cdot 81\end{array}$ \\
\hline Total & 9,430 & 66 & & 6,513 & 54 & & 2,917 & 12 & \\
\hline
\end{tabular}




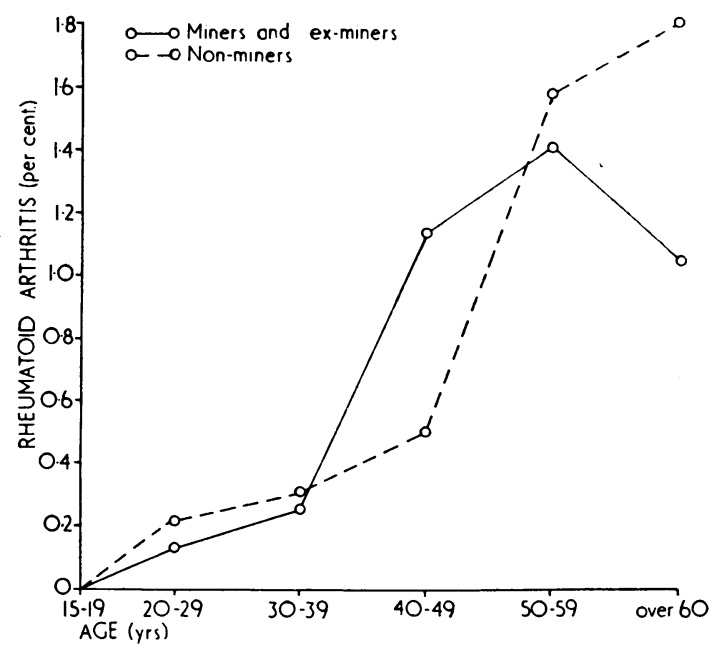

Fig. 2.-Prevalence of rheumatoid arthritis amongst miners and ex-miners and non-miners (Rhondda Fach, 1953).

on only twelve cases, whereas there were 54 cases amongst miners and ex-miners.

The similarity in the prevalence of arthritis between the mining and non-mining male populations, in spite of the very high prevalence of massive fibrosis amongst the miners, suggests that complicated pneumoconiosis is unlikely to be of aetiological importance in this disease.

\section{(d) Relationship with Pulmonary Disease}

(i) Miners and Ex-Miners.-Full-size chest radiographs were taken of all the 54 miners and of ten of the twelve non-miners with rheumatoid arthritis.

Table II shows the chest $x$-ray results in the miners with arthritis compared with those of an agebalanced control group selected at random from those without arthritis. It must be remembered that, in this area, 50 per cent. of the miners and exminers over the age of 35 show some radiological abnormality.

It is, nevertheless, striking that only thirteen of the 54 arthritics ( 24 per cent.) had normal $x$ rays com- pared with 24 of the 54 controls ( 44 per cent.), and whereas 25 of the rheumatoid arthritis cases (46 per cent.) showed massive fibrosis, this condition was present in only ten of the control group (19 per cent.). There was also a slight increase in the amount of active or inactive post-primary tuberculosis in the rheumatoid arthritis group-ten cases as compared with six in the controls. For statistical analysis, pleurisy has been grouped with post-primary tuberculosis; applying the usual contingency table test, $\chi^{2}=14 \cdot 14$ with three degrees of freedom, and $0.01>P>0.001$, i.e. results as diverse as those shown in Table II would not be expected by chance alone in 1 trial in 100 .

The distinction between progressive massive fibrosis and tuberculosis is frequently difficult radiologically. Tuberculous lesions, in the presence of simple pneumoconiosis, may retain all the radiological features of tuberculosis, but this is not always the case, and every gradation between characteristic tuberculous infiltration and obvious progressive massive fibrosis may be found, so that the distinction between the two is often arbitrary.

The type of nodular lung fibrosis described by Caplan and illustrated in Fig. 1 has only been seen in those who have been exposed to industrial dust inhalation of some kind, though it is not confined to coalworkers. In Belgium, Colinet (1950) described a somewhat similar syndrome in a woman who had been engaged in handling siliceous dusts. Radiologically, in coal-workers, these rounded opacities often develop upon a less severe grade of simple pneumoconiosis than does ordinary massive fibrosis; those in which the background of simple pneumoconiosis is less than Category 2 (International Classification) were routinely read as tuberculosis, whereas those with Category 2 or more were included in the P.M.F. group. The number of cases of Caplan's syndrome coming in these two columns of Table II are indicated in brackets, and together they account exactly for the difference between the rheumatoid and the control groups.

(ii) Non-Miners.-The chest $x$ rays of the nonmining males with arthritis show a similar excess of

TABLE II

COMPARISON OF CHEST RADIOGRAPHS OF MINERS AND EX-MINERS WITH AND WITHOUT RHEUMATOID ARTHRITIS (RHONDDA FACH, 1953)

\begin{tabular}{|c|c|c|c|c|c|c|c|c|c|c|c|c|c|}
\hline \multirow{2}{*}{ Group } & & \multicolumn{2}{|c|}{$\begin{array}{c}\text { Progressive } \\
\text { Massive Fibrosis }\end{array}$} & \multicolumn{2}{|c|}{$\begin{array}{l}\text { Post-Primary } \\
\text { Tuberculosis }\end{array}$} & \multicolumn{2}{|c|}{ Pleurisy } & \multicolumn{2}{|c|}{$\begin{array}{c}\text { Simple } \\
\text { Pneumoconiosis }\end{array}$} & \multicolumn{2}{|c|}{ Normal } & \multicolumn{2}{|c|}{ Total } \\
\hline & & No. & Per cent. & No. & Per cent. & No. & Per cent. & No. & Per cent. & No. & Per cent. & No. & Per cent. \\
\hline Rheumatoid & $\ldots$ & $25(15) *$ & 46 & $10(4) *$ & 19 & 1 & 2 & 5 & 9 & 13 & 24 & 54 & 100 \\
\hline Control & $\ldots$ & 10 & 19 & 6 & 11 & 1 & 2 & 13 & 24 & 24 & 44 & 54 & 100 \\
\hline
\end{tabular}

* Cases of Caplan's syndrome are indicated in brackets. 
COMPARISON OF CHEST RADIOGRAPHS OF NON-MINERS WITH AND WITHOUT RHEUMATOID ARTHRITIS (RHONDDA FACH, 1953)

\begin{tabular}{|c|c|c|c|c|c|c|c|c|c|c|}
\hline \multirow{2}{*}{\multicolumn{2}{|c|}{ Group }} & & \multicolumn{2}{|c|}{$\begin{array}{l}\text { Post-Primary } \\
\text { Tuberculosis }\end{array}$} & \multicolumn{2}{|c|}{ Pleurisy } & \multicolumn{2}{|c|}{ Normal } & \multicolumn{2}{|c|}{ Total } \\
\hline & & & No. & Per cent. & No. & Per cent. & No. & Per cent. & No. & Per cent. \\
\hline Rheumatoid & . & $\ldots$ & 4 & 40 & 1 & 10 & 5 & 50 & 10 & 100 \\
\hline Control & . & .. & 1 & 5 & - & - & 19 & 95 & 20 & 100 \\
\hline
\end{tabular}

post-primary tuberculosis over their age-balanced control group, which was double the size and was selected at random from the non-mining male population without rheumatoid arthritis (Table III). Four of the ten showed evidence of post-primary tuberculosis, three of the four being considered to have clinically significant disease; one other showed evidence of pleurisy; in the control group only one case of healed post-primary tuberculosis was noted.

For analysis, pleurisy has again been grouped with post-primary tuberculosis. Although the numbers are small, the association between rheumatoid arthritis and changes in the chest radiographs is again statistically significant $(0.05>P>0.01)$.

(e) Heredity in Rheumatoid Arthritis.-An investigation to determine the importance of genetic factors in rheumatoid arthritis was made by enquiring into the presence of the disease in parents and siblings of these cases and comparing them with those of a control group. The inquiry was limited to parents and siblings so that more reliance could be placed upon the data, and where possible the diagnosis was confirmed by visiting secondary cases living near the valley. Where this was impossible, data were obtained by questionnaire. If the affected relative had died or could not be visited, only clearcut histories were accepted.

Family histories were available for 61 of the 66 men with arthritis: in three cases the relatives were unknown; one refused to co-operate; and the other was living away at the time of this later investigation.
Two pairs of brothers occur in this group of 61 cases\% to include these four men as index cases would exaggerate the importance of heredity and one of each pair has been omitted. This study is therefore based upon 59 rheumatoid arthritis index cases an 89 index controls, of the same age as the arthritics? who were selected at random from the inhabitants of the valley (Table IV).

Histories were available for 110 parents and 244 siblings of the 59 index cases, and for 168 parents and 334 siblings of the 89 controls (over 90 per cent. of the relatives of controls who were living in the valley were also examined).

The family sizes were very similar in the tw $\underline{8}$ groups; the mean ages of the parents differed by les than 1 year, the mean age of the siblings was 4 yers? greater in the control group.

Amongst the 354 relatives of index cases, ele secondary cases were found $(3 \cdot 1$ per cent.). These occurred in eight families. In each of five of thes: families two cases of rheumatoid arthritis wers found, in each of the other three families there wer three cases; eight of the eleven secondary cases were confirmed by visiting, the remainder by question? naire. In the 502 relatives of controls, three cases of rheumatoid arthritis were found (0.6 per cent. These differences are statistically significant.

Stecher and his colleagues (1953) report similar findings in a larger scale investigation in the Unite, States. They investigated the disease in 1,45 量 parents, siblings, and children of 224 index cases of

TABLE IV

INCIDENCE OF RHEUMATOID ARTHRITIS AMONGST PARENTS AND SIBLINGS OF 59 MALE CASES AND 89 CONTROLS (RHONDDA FACH, 1953)

\begin{tabular}{|c|c|c|c|c|c|c|c|c|c|c|c|c|c|}
\hline \multirow[b]{2}{*}{ Index Cases } & \multirow[b]{2}{*}{ No. } & \multicolumn{4}{|c|}{ Parents } & \multicolumn{4}{|c|}{ Siblings } & \multicolumn{3}{|c|}{ Parents and Siblings } & \multirow[b]{2}{*}{ Pero } \\
\hline & & $\begin{array}{l}\text { Histories } \\
\text { Available }\end{array}$ & $\begin{array}{c}\text { Mean } \\
\text { Age } \\
\text { (yrs) }\end{array}$ & $\begin{array}{c}\text { Rheuma- } \\
\text { toid } \\
\text { Arthritis }\end{array}$ & $\begin{array}{c}\text { Per } \\
\text { cent. }\end{array}$ & $\begin{array}{l}\text { Histories } \\
\text { Available }\end{array}$ & $\begin{array}{c}\text { Mean } \\
\text { Age } \\
\text { (yrs) }\end{array}$ & $\begin{array}{c}\text { Rheuma- } \\
\text { toid } \\
\text { Arthritis }\end{array}$ & $\begin{array}{c}\text { Per } \\
\text { cent. }\end{array}$ & \begin{tabular}{|l|} 
Histories \\
Available
\end{tabular} & $\begin{array}{c}\text { Mean } \\
\text { Age } \\
\text { (yrs) }\end{array}$ & $\begin{array}{c}\text { Rheuma- } \\
\text { toid } \\
\text { Arthritis }\end{array}$ & \\
\hline $\begin{array}{c}\text { Rheumatoid } \\
\text { Arthritis }\end{array}$ & 59 & 110 & $63 \cdot 5$ & 1 & 1 & 244 & $44 \cdot 3$ & 10 & $4 \cdot 1$ & 354 & $51 \cdot 4$ & 11 & $3 \cdot 1 \frac{\mathrm{C}}{\mathrm{D}}$ \\
\hline Control & 89 & 168 & $64 \cdot 2$ & 3 & 2 & 334 & $48 \cdot 3$ & - & - & 502 & $53 \cdot 0$ & 3 & $0.6^{5}$ \\
\hline
\end{tabular}

Only relatives over the age of 25 years have been considered. For dead relatives, age at death has been used, if over 25 years. 
both sexes, and reported $3 \cdot 1$ per cent. of the relatives affected. When the children are excluded the incidence rises to 3.7 per cent., compared with the 3.1 per cent. in the Rhondda Fach. Unfortunately, the data quoted for controls by these authors cannot be directly compared with the Rhondda data, as they included an unstated number of children of index cases. It seems likely, however, that the results of the two surveys are of the same order of magnitude, for Stecher and others report 0.58 per cent. of affected individuals (when control index cases without arthritis are included), compared with 0.51 per cent. for the Rhondda when control index cases are included.

In the Empire Rheumatism Council investigation (Lewis-Faning, 1950) 3.8 per cent. of siblings of rheumatoid arthritics were reported to be affected, compared with 1.8 per cent. of siblings of controls, but the data for arthritis in parents are not restricted to rheumatoid arthritis.

Short and others (1949) reported positive family histories in 11.9 per cent. of patients and 5.1 per cent. of controls. The results of this survey, expressed similarly would be 13.6 per cent. and $3 \cdot 4$ per cent. respectively.

Thus, in spite of the acknowledged weaknesses of this type of investigation due to the greater awareness of affected relatives of patients suffering from the condition, it seems certain that heredity is an aetiological factor of importance in this disease.

(f) Occupational History. - In a previous paper (Miall and others, 1953) the duration of exposure to stone dust appeared possibly to be an important factor in the development of Caplan's syndrome. An analysis of the industrial histories of all the miners and exminers with rheumatoid arthritis showed that stonedust exposure occurred no more frequently in them than in an age-balanced control group, and though amongst the rheumatoid arthritics the cases with Caplan's syndrome show a higher proportion with stone-dust exposure, the difference is not statistically significant.

\section{Comparison of Prevalence Data with Other Surveys}

There have been few other surveys of rheumatic diseases in complete or randomly sampled communities, and in none have the results of any objective tests used in the diagnosis been published.

In the British Isles, the Newman report (Ministry of Health, 1924) was based upon general practitioners' records for the employed population covered by the National Health Insurance. The rate quoted for men is similar to that found in the Rhondda in the younger age groups, but, as would be expected, the rate in older males is much lower than in the Rhondda.

Nisbet (1946) gives an incidence of $0 \cdot 17$ per cent. in Scottish males over the age of 15 years. Both Nisbet and the Sickness Survey (Stocks, 1949), which quotes a figure of 0.42 per cent. for males and females over the age of 16 (based on self-diagnosis), found a higher prevalence of rheumatoid than osteo-arthritis, a most unusual finding.

A Royal Commission on Rheumatic Diseases in Sweden (1945) estimated that $0 \cdot 25$ per cent. of the total Swedish population was suffering from rheumatoid arthritis during 1943. Kalbak (1953) reported the prevalence amongst in-patients and out-patients and the disabled in Denmark, but in a survey of rheumatism in the general population, no breakdown by type of disease is published.

De Blécourt and Basart (1953), on a sampling basis, found 0.81 per cent. of males over the age of 13 with rheumatoid arthritis in Holland.

Kellgren and his colleagues (1953) found a higher prevalence than any of these other workers, but his survey was carried out in Lancashire, where, according to the Newman report, all types of rheumatism are increased. Kellgren reports 1.7 per cent. amongst males, based on complaints within the preceding 5 years.

The prevalence of rheumatoid arthritis cases which satisfy the strict criteria used in this survey amongst males over the age of 15 years in the Rhondda is found to be 0.7 per cent.

\section{Discussion}

This survey of rheumatoid arthritis amongst males living in a Welsh mining valley was designed to study the relationship between that disease and pulmonary abnormalities. In particular, it was important to determine whether massive fibrosis was responsible for an increase of rheumatoid arthritis in miners; it had already been shown that the prevalence of this type of arthritis was high amongst cases of massive fibrosis. The survey showed that though the prevalence of rheumatoid arthritis amongst all cases of massive fibrosis is about $2 \cdot 7$ per cent., compared with 0.6 per cent. amongst miners without massive fibrosis, the prevalence of the disease in miners does not differ significantly from that amongst non-miners, and therefore it is most unlikely that massive fibrosis is in any way predisposing to rheumatoid arthritis.

The difference in the shape of the two curves shown in Fig. 2, though not statistically significant, may represent an epidemiological difference which would have been significant had the numbers been 
greater. An analysis by age at onset might have thrown further light on any difference between the two groups; such an analysis, however, is impossible, as in the past there have been few opportunities for occupation other than mining, so that most cases in which there is a late onset of arthritis fall into the mining group.

The attack rate of rheumatoid arthritis, as deduced from the prevalence data, is considerable, and our findings, which are in agreement with those of Stecher and others (1953) and Lewis-Faning (1950), show that more than 50 per cent. occurs over the age of 40 years. Death rates, as quoted by the RegistrarGeneral (Brooke, 1952), are extremely low, less than 20 per million living. With this sustained attack rate over the age of 40 and this low mortality rate, we should expect the prevalence rate to increase steadily at least to the age of 60 years, as it appears to do in the non-mining males. The shape of the prevalence curve for miners and ex-miners can be explained by an increasing attack rate or by an increased mortality rate (or an increased migration rate from the valley) in men with arthritis. The data are insufficient to explain which, if any, of these three factors is operating.

Almost half the patients with rheumatoid arthritis amongst miners show massive fibrosis (46 per cent.), and a further 19 per cent. show evidence of postprimary tuberculosis; the corresponding figures are 19 per cent. and 11 per cent. in the control group of miners without arthritis.

As the excess of tuberculosis and massive fibrosis in the miners disappears when cases of Caplan's syndrome are excluded, it could be argued that this is evidence that such cases are of a different aetiology, but no other evidence supports such a view. It is possible that this is so; more than one type of inflammatory focus in dust-laden lungs may initiate massive fibrosis.

Much evidence suggests that complicated pneumoconiosis is a tuberculous condition (Rogers, 1946; Fletcher and Gough, 1950; Van Mechelin, 1953; James, 1954). There are no pathological features to suggest a different aetiology for Caplan's syndrome, and, in fact, two of the 32 cases which have been fully investigated as in-patients, have had tubercle bacilli in the sputum.

If we accept as a working hypothesis that complicated pneumoconiosis is a modified form of tuberculosis, and that Caplan's syndrome is a modification of complicated pneumoconiosis, we must seek some explanation of this difference in the amount of chest $x$ ray abnormalities between rheumatoid arthritics and other men.

It appears probable that massive fibrosis and tuberculosis are not of aetiological importance i卬 rheumatoid arthritis. We must therefore postulate that patients with rheumatoid arthritis are more liable to show radiological changes of this kind thaף. normal people. If this is true, is the difference one of environment or one of tissue response?

There is no evidence to suggest that environmentalt factors are responsible; there is, however, some evidence to suggest an abnormal tissue response i $\bar{x}$. some cases of rheumatoid arthritis.

It has already been shown that hereditary factors are of importance in rheumatoid arthritis. What 2 ever factors comprise the rheumatoid diathesis, on $\overrightarrow{0}$ may be associated with an altered tissue response to infections.

That there is an altered tissue reaction in the lunge in at least some cases of rheumatoid arthritis is sug? gested by Caplan's syndrome itself. Furthermores in studying this syndrome, we find cases in which the lung lesions precede the onset of arthritis by severati years, and conversely others in which they develog several years after its onset. This fact alone $\frac{18}{8}$ difficult to explain except in terms of some altered tissue reaction in those liable to rheumatoid arthritis

This concept is supported also by the finding of three cases of Caplan's syndrome in one familys a father and two of his three sons.

In our enquiry into the familial incidence af rheumatoid arthritis, additional cases were foun 13.6 per cent. of families. One purpose of inquiry was to see whether those miners with the Caplan type of chest $x$-ray appearance but withoug arthritis had a similar familial incidence of rheuma toid arthritis, and this seems to be so; seventeen such cases have been seen and in two of them parents of siblings had been affected (12 per cent.).

Any attempt to explain the chest $x$-ray finding reported here must be speculative. It has been demonstrated by Kettle (1934) and more recently by Attygalle and others (1954) that the degree of. fibrosis produced by the intra-tracheal injection $\Phi$ a combination of dust and killed avirulent tubercle bacilli (B.C.G.) in experimental animals is greates than that obtained by either of these agents alone If a similar synergic process occurs in man the might explain the lack of reported cases resembling Caplan's syndrome in those with no history of exposure to dust inhalation; but to account for the characteristic features of Caplan's syndrome and the increased prevalence of radiological opacities found in men with rheumatoid arthritis we must postulate some additional factor peculiar to them.

This additional factor may be associated with a unusual susceptibility to all infections. Cobb anth his colleagues (1953) have reported that the cause 
of death in rheumatoid arthritis differ from the causes in the general population, and amongst those causes is an increased frequency of infections of all kinds.

But if, as Kellgren (1952) has suggested, the fundamental abnormality in rheumatoid disease involves the disintegration of the collagen-polysaccharide complex of normal connective tissue, it is possible that these radiological findings represent not only the reaction of the lungs to tuberculosis, whether or not it is modified by dust, but also a secondary reaction to changes occurring in the collagen of complicated pneumoconiosis and tuberculosis.

\section{Conclusions}

This survey raises again the much discussed relationship between rheumatoid arthritis and tuberculosis. Poncet (1902) first suggested that rheumatoid arthritis could be of tuberculous origin, and many papers since then have appeared with descriptions of cases of rheumatoid arthritis accompanied by active tuberculosis (Copeman, 1936; Sheldon, 1946; Dalgleish, 1952; and others). The literature on this subject has been well reviewed by Brav and Hench (1934). As is stated in Rheumatism and Arthritis: Review of American and English Literature of Recent Years (1953), "There are no convincing data supporting the concept of "tuberculous rheumatism'."

Though tuberculosis as a cause of rheumatoid arthritis is improbable, the evidence presented here suggests that a relationship between the two diseases may exist and that this relationship is due to some alteration in tissue reaction which is often of genetic origin and perhaps a component of the so-called "rheumatoid diathesis".

\section{Summary}

(1) An epidemiological survey of rheumatoid arthritis in a complete community of 9,430 males over the age of 15 years has been carried out in South Wales to determine the relationship between this disease and pulmonary abnormalities.

(2) All cases found were asked to submit to $x$ rays of chest, hands, and feet, and to a differential agglutination test; criteria confirmed by objective evidence were used in the diagnosis of rheumatoid arthritis.

(3) No increased prevalence of rheumatoid arthritis was found amongst miners and ex-miners in this community where progressive massive pulmonary fibrosis and cases of Caplan's syndrome are prevalent. It is concluded, therefore, that neither exposure to dust nor the lung changes of complicated pneumoconiosis are of any aetiological importance in the disease.

(4) A significantly high prevalence of massive fibrosis and tuberculosis was found amongst the miners with arthritis, and a significantly high prevalence of tuberculosis was found amongst the non-miners.

(5) We have confirmed the findings of others that inheritance is of importance in the aetiology of this disease. This is also true of Caplan's syndrome and of cases found with the characteristic Caplan chest $x$ ray without arthritis.

(6) Caplan's syndrome and the present findings suggest an inherited abnormality of tissue reaction, not confined to the skeletal system, in those with, or presumably liable to develop, rheumatoid arthritis.

(7) This hypothesis would account for the numerous descriptions of cases of rheumatoid arthritis accompanied by active tuberculosis which have appeared since Poncet described tuberculous rheumatism in 1902, but it does not confirm Poncet's view that tuberculosis is a cause of rheumatoid arthritis.

This survey depended upon the active co-operation of many disabled people in the Rhondda Fach, and I should like to record my thanks to them and to the many others who so willingly helped in this work.

Assistance was given by Dr. A. Caplan, of the Pneumoconiosis Medical Panel, Cardiff, and by my colleagues at the Pneumoconiosis Research Unit. In particular, Dr. J. C. Gilson, the Director, and Dr. A. L. Cochrane gave much helpful criticism and advice, Mr. R. G. Carpenter undertook the statistical analysis, and the Unit's epidemiological and radiological teams carried out much of the field work involved.

It is a pleasure to acknowledge my indebtedness also to Prof. J. H. Kellgren who gave invaluable advice and kindly read the $x$ rays of the peripheral joints, to Dr. J. Ball who undertook the differential agglutination tests, to Drs. A. L. Cochrane and V. H. Springett who read the chest $x$ rays, and to Dr. J. F. Brailsford who also gave radiological advice. Dr. Griffith Jones kindly provided information about a number of patients under his care.

\section{REFERENCES}

Attygalle, D., Harrison, C. V., King, E. J., and Mohanty, G. P. (1954). Brit. J. industr. Med., 11, 245.

Ball, J. (1950). Lancet, $2,520$.

(1952). Annals of the Rheumatic Diseases, 11, 97. (1955). Ibid., 14, 159.

de Blécourt, J. J., and Basart, A. H. M. (1953). "Investigation as to the Prevalence of Rheumatic Diseases and to their Dependence upon the Degree of Dampness in Dwellings." Report
No. 20. Research Institute for Public Health Engineering. T.N.O. Holland.

Brav, E. A., and Hench, P. S. (1934). J. Bone Jt Surg., 16, 839. Brooke, E. M. (1952). Mon. Bull. Minist. Hith. Lab. Serv., 11, 57. Caplan, A. (1953). Thorax, 8, 29. Cobb, S., Anderson, F., and Bauer, W. (1953). New Engl. J. Med.,
249, 553. 
Cochrane, A. L., Cox, J. G., and Jarman, T. F. (1952). Brit. med. J., 2, 843 .

$-\frac{2}{1950}$ (1955). Brit. med. J., 1, 371.

Colinet, E.'(1950). Acta physioth. rheum. belg., 5, 185.

Copeman, W. S. C. (1936). Proc. Mayo Clin., 11, 568.

Dalgleish, P. G. (1952). Annals of the Rheumatic Diseases, 11, 222.

Fletcher, C. M., and Gough, J. (1950). Brit. med. Bull., 7, 42.

James, W. R. L. (1954). Brit. J. Tuberc., 48, 89.

Kalbak, K. (1953). Annals of the Rheumatic Diseases, 12, 306.

Kellgren, J. H. (1952). Brit. med. J., 1, 1093, 1152.

Kellgren, J. H. (1952). Brit. med. J., 1, 1093, 1152.

二-, and Lawrence, J. S. (1952). Brit. J. industr. Med., 9, 197. Diseases, 12, 5.

-

Kettle, E. H. (1934). J. Path. Bact., 38, 201.

Lewis-Faning, E., ed. (1950). "Empire Rheumatism Council Report on an Inquiry into the Aetiological Factors associated with Rheumatoid Arthritis", Annals of the Rheumatic Diseases, Suppl. to vol. 9.

Miall, W. E., Caplan, A., Cochrane, A. L., Kilpatrick, G. S., and Oldham, P. D. (1953). Brit. med. J., 2, 1231.

Ministry of Health (1924). "The Incidence of Rheumatic Diseases" ed. G. Newman. Reports on Public Health and Medical Subjects, No. 23. H.M.S.O., London.

Nisbet, B. R. (1946). Annals of the Rheumatic Diseases, 5, 168.

Poncet, A. (1902). Lyon méd., 99, 65.

Rheumatism and Arthritis: Review of American and English Literature of Recent Years (1953). Ann. intern. Med., 39, 498.

Rogers, E. (1946). Lancet, 1, 462 .

Rose, H. M., Ragan, C., Pearce, E., and Lipman, M. O. (1948). Proc. Soc. exp. Biol. (N.Y.), 68, 1.

Sheldon, W. (1946). Lancet, 1, 119.

Short, C. A., Abrams, N. R., and Sartwell, P. E. (1949). Annals of the Rheumatic Diseases, 8, 313.

Statens Offentliga Utredningar (1945). "Års Reumatikervårdssakkunniga, 1941." Stockholm.

Stecher, R. M., Hersh, A. H., Solomon, W. M., and Wolpaw, R. (1953). Amer. J. hum. Genet., 5, 118.

Stocks, P. (1949) "Sickness in the Population of England and Wales in 1944-1947." General Register Office, Studies on Medical and Population Subjects, No. 2. H.M.S.O., London.

Van Mechelen, V. (1953). Verh. vlaam. Akad. Geneesk. belg., 15, 281 .

Arthrite rheumatismale chez le mâle

Etude épidémiologique d'une communauté minière galloise

\section{RÉSUMÉ}

(1) On a procédé a une étude épidémiologique de l'arthrite rhumatismale dans une communauté complète des Galles du Sud chez 9.430 mâles âgés de plus de 15 ans pour déterminer le rapport entre cette maladie et les anomalies pulmonaires.

(2) On a demandé à tous les cas décélés de se soumettre à la radiologie des poumons, des mains et des pieds et à la réaction d'agglutination différencielle; pour le diagnostic $\mathrm{d}$ arthrite rhumatismale on s'est imposé des critères déterminés confirmés par des preuves objectives.

(3) On n'a pas trouvé que la fréquence d'arthrite rhumatismale soit exagérée chez les mineurs et les anciens mineurs de cette communauté, dans laquelle la fibrose pulmonaire massive et progressive et le syndrome de Caplan se voient si souvent. On en conclut, que l'exposition à la poussière et les altérations pulmonaires compliquant la pneumoconiose ne constituent pas un facteur étiologique important de la maladie rhumatismale.

(4) On a trouvé que la fibrose massive et la tuberculose étaient appréciablement plus fréquentes chez les mineurs atteints d'arthrite et une prédominance appréciable de la $\frac{\bar{T}}{\overparen{D}}$
tuberculose s'est observée chez les non-mineurs.

(5) Nous avons confirmé les résultats des autres que l'hérédité joue un rôle important dans l'étiologie de cette maladie. Il en est de même pour le syndrome de Caplan, avec son image radiologique pulmonaire caractéristique, même sans arthrite.

(6) Le syndrome de Caplan et les résultats obtenus ici suggèrent l'existence d'une anomalie héréditaire de la réaction tissulaire qui, chez les rhumatisants ou ceux드 susceptibles de le devenir, ne se limite pas au système $\overline{\bar{\sigma}}$ ostéo-cartilagineux.

(7) Cette hypothèse expliquerait les cas d'arthrite@ rhumatismale associée à la tuberculose évolutive, siô souvent rapportés depuis que Poncet (1902) a décrit le $e_{-}^{\infty}$ rhumatisme tuberculeux, sans toutefois confirmer $\overrightarrow{0}$ l'opinion de Poncet que la tuberculose soit la cause del'arthrite.

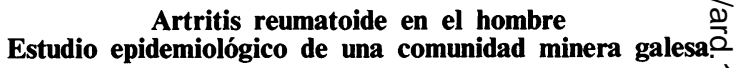

\section{Sumario}

(1) Se estudió la epidemiología de la artritis reumatoide en una comunidad completa de las Gales de Sur encr 9.430 hombres de más de 15 años de edad para deter-? minar la relación entre esta enfermedad y las anomalías pulmonares.

(2) Se pidió a todos los casos descubiertos que sec sometieran a la radiología del pecho, de las manos y de los pies, así como a la reacción de aglutinación diferencial. $\overparen{D}$ Para el diagnóstico de la artritis reumatoide se impuso $\overrightarrow{0}$ criterios determinados confirmados por hechoser onjetivos.

(3) No se halló frecuencia exagerada de artritis reuntoide en los mineros o antiguos mineros de esta comugi dad, en la cual la fibrosis pulmonar masiva y progres y el sindrome de Caplan abundan. Se concluye que laō exposición al polvo o alteraciones pulmonares com-0ّ plicando la pneumoconiosis no constituyen un factor@ etiológico importante en la enfermedad reumática.

(4) Se halló que la fibrosis masiva y la tuberculosisō fueron significativamente más frecuentes en mineros con 3 artritis mientras que en los que no eran mineros hubo preponderancia de la tuberculosis.

(5) Confirmamos los resultados de otros autores que. la herencia juega un papel importante en la etiología de esta enfermedad. Esto es aplicable al síndrome de Caplan? con su cuadro radiológico pulmonar característico, aún sin artritis.

(6) El síndrome de Caplan y los resultados obtenidosi aquí sugieren una anomalía hereditaria de la reacción des los tejidos que en sujetos reumáticos o con terreno reumático no se limita al sistema óseo-cartilaginoso.

(7) Esta hipótesis explicaría los casos de artritis reumatoide asociados a la tuberculosis activa, relatados. en gran número desde que Poncet (1902) había descrito. el reumatismo tuberculoso, sin confirmar la opinion dê Poncet que la tuberculosis sea la causa de la artritis. 